\title{
Allium cepa L. responses when Gaeolaelaps aculeifer Canestrini and Parasitus bituberosus Karg are used to control Thrips tabaci Lindeman
}

\section{Respuesta de Allium cepa L. en presencia de Gaeolaelaps aculeifer Canestrini y Parasitus bituberosus Karg para el control de Thrips tabaci Lindeman}
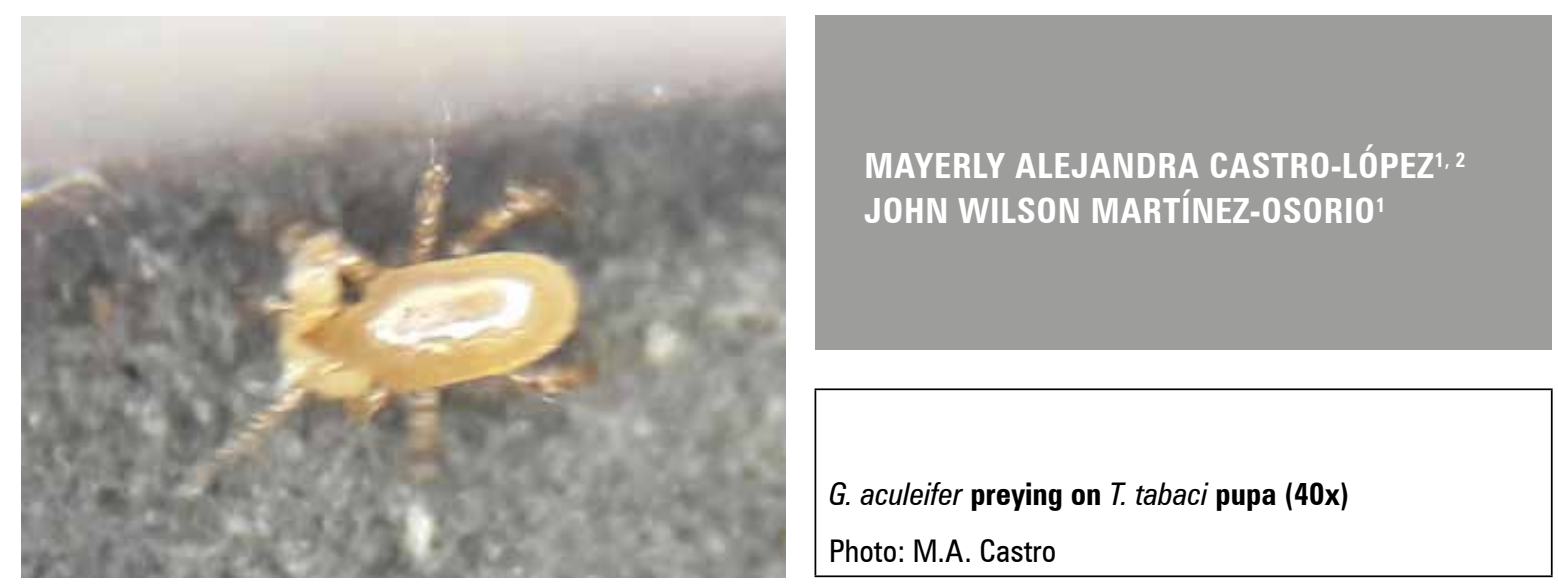

\section{ABSTRACT}

Thrips tabaci Lindemann is the main insect pest of Allium cepa L., causing both direct and indirect damage to crops. T. tabaci is controlled by applying chemically synthesized products; however, this insect has already developed resistance to organophosphates, carbamates, and pyrethroids. This study evaluated the effect of soil predatory mites (Gaeolaelaps aculeifer Canestrini and Parasitus bituberosus Karg) on the population density of T. tabaci in potted bulb onion (Allium cepa L.) plants and on the response of physiological variables related to photosynthesis and plant development. Seven treatments were evaluated that released 50, 75 or $100 \mathrm{G}$. aculeifer or $P$. bituberosus adults, along with a control without predatory mites. Significant differences $(P \leq 0.05)$ in the population density of T. tabaci were observed for 13 weeks, with a 78\% reduction of individuals in the presence of G. aculeifer and a $72 \%$ reduction with P. bituberosus, regardless of mite density, as compared to the control. In addition, the relative chlorophyll index, foliar area, dry leaf weight and fresh bulb weight increased, as compared to the control. The application of 100 individuals of the two species recorded the highest values in the evaluated variables. These results indicate that G. aculeifer and P. bituberosus controls should be explored as an option for integrated T. tabaci management.

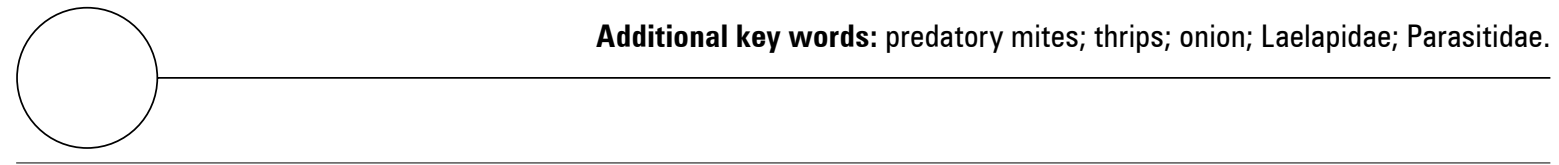

Universidad Pedagógica y Tecnológica de Colombia, Facultad de Ciencias Agropecuarias, Grupo Manejo Biológico de Cultivos, Tunja (Colombia). ORCID Castro-López, M.A.: 0000-0003-1151-2514; ORCID Martínez-Osorio, J.W.: 00000002-5742-8062

${ }^{2}$ Corresponding author. macastrol@unal.edu.co 


\section{RESUMEN}

La principal limitante del cultivo de Allium cepa L. es Thrips tabaci dado que genera daños directos e indirectos en el cultivo. El principal método de control es mediante productos de síntesis química, no obstante, este insecto ya presenta resistencia a ingredientes activos como organofosforados, carbamatos y piretroides. Por tal razón, este estudio consistió en evaluar la densidad poblacional de T. tabaci y la respuesta de variables fisiológicas relacionadas con la fotosíntesis y desarrollo de plantas de cebolla de bulbo a la presencia de ácaros depredadores del suelo como Gaeolaelaps aculeifer Canestrini y Parasitus bituberosus Karg, los cuales pueden alterar el ciclo de vida de los trips, especialmente la fase de pupa presente en el suelo. Se evaluaron siete tratamientos que consistieron en la liberación en plantas de cebolla de 50, 75 y 100 adultos de G. aculeifer, 50, 75 y 100 adultos de P. bituberosus y un testigo sin ácaros depredadores. Se observaron diferencias significativas $(P \leq 0,05)$ en la densidad poblacional de T. tabaci al final del experimento, con una reducción de individuos de $78 \%$ en presencia de G. aculeifer y $72 \%$ con P. bituberosus. Así mismo, hubo reducción en el índice relativo de clorofila, área foliar, peso foliar seco y peso fresco del bulbo en comparación con el testigo. La aplicación de 100 individuos de las dos especies de ácaros, registró los valores más altos en las variables evaluadas. Estos resultados indican que G. aculeifer y P. bituberosus puede ser una opción de control a explorar más a fondo dentro de un esquema de manejo integrado de T. tabaci.

Palabras clave adicionales: ácaros depredadores; trips; cebolla; Laelapidae; Parasitidae.

Received: 13-05-2020 Accepted: 03-12-2020 Published: 13-01-2021

INTRODUCTION

Predatory mites of the Mesostigmata order represent potential biological control agents for agricultural pests (Carrillo et al., 2015). Previous studies have found species of the families Laelapidae and Parasitidae in soils of bulb onion (Allium cepa L.) crops in the Department of Boyaca (Castro-Lopez, 2018), including Gaeolaelaps aculeifer (Canestrini) (Laelapidae), which is used commercially in European and North American crop production for controlling thrips, mites, and flies (van Lenteren, 2012). Likewise, Parasitus bituberosus (Karg) (Parasitidae) is a promising species for managing fly larvae, (Szafranek et al., 2013) thrips, and nematodes (Rueda-Ramírez et al., 2019).

The bulb onion is one of the more important vegetables worldwide (Pinzón, 2009). The presence of Thrips tabaci Lindeman (Thysanoptera: Thripidae) in bulb onion crops is a challenge for production (Vergel et al., 2017) because it reduces bulb size by up to $60 \%$ (Rueda et al., 2007). This insect reduces the photosynthetic capacity by feeding on onion leaves (Jensen et al., 2003), accelerating leaf senescence with the physiological stress that results from the foliar damage (Kendall and Bjostad, 1990). It is also a vector of the Iris yellow spot virus (Bunyaviridae: Tospovirus), which reduces bulb size and quality (Muñoz et al., 2014).
Management strategies for T. tabaci include the application of chemically synthesized products. However, T. tabaci populations have been reported to be resistant to several insecticides, including organophosphates, carbamates and pyrethroids in the United States (Shelton et al., 2006), spinosad in Israel (Lebedev et al., 2013), and deltrametrin and diazinon in New Zealand (Martin et al., 2003). In South America, resistance to these chemicals is unknown. In addition, not all insect stages of development are equally affected by chemical treatments (Damte et al., 2017). Prepupae and pupae are protected by the soil or the base of onion plants and may escape contact with insecticides (Gill et al., 2015). Therefore, management strategies that include biological control should be explored.

Gaeolaelaps aculeifer is an edaphic mite that is used commercially for biological control in Europe and North America. This mite is a generalist predator that can feed on a wide range of prey, including astigmatic mites (Rueda-Ramírez et al., 2018), nematodes (Moreira and Moraes, 2015), fly larvae (Sardar and Murphy, 1987), and collembolans (Heckmann et al., 2007). A Colombian population of this predator was found to consume approximately 2.6 Frankliniella occidentalis (Pergande) pre-pupae or pupae daily per adult 
female (Rueda-Ramírez et al., 2018). In bean plants, a predation rate of $80.5 \%$ for $F$. occidentalis was reported for $14 \mathrm{~d}$ (Berndt et al., 2004); in citrus, consumption reached for 12.3 \pm 0.8 Pezothrips kellyanus (Bagnall) over $3 \mathrm{~d}$ (Navarro-Campos et al., 2012). There are no studies on this predatory mite for T. tabaci.

Parasitus bituberosus is another edaphic mite that has been reported as a potential biological control agent, feeding on fly larvae (Al-Amidi and Downes, 1990; Al-Amidi et al., 1991; Szafranek et al., 2013), nematodes (Szafranek et al., 2013; Rueda-Ramírez et al., 2019), and forpigarous mites (Szafranek et al., 2013). Recently, a study observed the consumption of 2.5 $\pm 0.8 \mathrm{~F}$. occidentalis pre-pupae and pupae daily per adult female (Rueda-Ramírez et al., 2019). This result indicated that this predator may prey on other thrips species, including T. tabaci.

Given these findings and the fact that pre-pupae and pupae stages of $T$. tabaci develop in the soil, the objective of this research was to evaluate the response of $A$. cepa plants to applications of $G$. aculeifer and $P$. bituberosus to control T. tabaci under greenhouse conditions.

\section{MATERIALS AND METHODS}

\section{Geographical location of the study area}

This research was carried out in a greenhouse at the Grupo Manejo Biologico de Cultivos (GMBC), Universidad Pedagógica y Tecnológica de Colombia (UPTC), in the municipality of Tunja, Department of Boyaca, Colombia, with an average daily temperature of $21 \pm 3^{\circ} \mathrm{C}$ and a relative humidity of $60 \pm 15 \%$.

In the greenhouse, $60 \mathrm{~A}$.cepa onion seedlings, acquired in the municipality of Tibasosa in the Department of Boyaca, were seeded. Six plants were placed in a $1 \mathrm{~m}^{2}$ square. Conventional management was used for the irrigation, fertilization, and other agronomic tasks to achieve good development of the plants.

The mite colonies were kept in breeding units, which consisted of an incubator chamber with a $19 \pm 3^{\circ} \mathrm{C}$ average temperature and $60 \pm 15 \%$ relative humidity, in the absence of light. This methodology was adapted from Freire and Moraes (2007). Gaeolaelaps aculeifer was fed a mixture of all developmental stages of Aleuroglyphus ovatus (Troupeau) (Sarcoptiformes,
Astigmatina, Acaridae), which was reproduced and reared on crushed commercial dog food (Purina $($ ) nutritional content: $9 \%$ fat, $12 \%$ moisture, $8 \%$ ash and $25 \%$ protein). Parasitus bituberosus was fed with A. ovatus and Rhabditidae nematodes maintained on bean pods (Phaseolus vulgaris L.).

\section{Evaluation of $G$. aculeifer and $P$. bituberosus for the control of $T$. tabaci in onion plants}

The onion plants were infested with $50 \mathrm{~T}$. tabaci adults that were collected from $A$. cepa crops in the municipalities of Tibasosa and Nobsa. After $60 \mathrm{~d}$, they were expected to have completed four life cycles. Afterwards, ethe prepupae and pupae were used as food for the predatory mites; different amounts of the mite predator species were released.

A completely randomized experiment design was used that included seven treatments: 50 (G50), 75 (G75), or 100 (G100) f G. aculeifer adults, 50 (P50), 75 (P75), or 100 (P100) P. Bituberosus adults, and a control without applications of the predator (control). Each treatment was replicated six times, for a total of 42 experiment units. Two releases of G50, G75, G100, P50, P75 and P100 were carried out for the treatments, at the beginning of assay and in the $8^{\text {th }}$ week.

Every 2 weeks, the T. tabaci population was assessed, recording all developmental stages (excluding the eggs of the thrips) found on three leaves in the central third of six plants per treatment. This method was used from the $5^{\text {th }}$ week until the $13^{\text {th }}$ week, which was the end of the growing cycle.

\section{Effects on bulb onion plants from the $G$. aculeifer and P. bituberosus}

To determine the effects on onion plant growth, five leaves were selected from the central third of each plant and treatment to measure the chlorophyll content (Minolta SPAD 502 plus chlorophyllmeter) every $15 \mathrm{~d}$, recording the average per plant, expressed in SPAD Units. At week 14, when maturity was reached, the foliar area was measured, expressed in $\mathrm{cm}^{2}$ were done, with a CI 202, Bio-Science Inc. The fresh and dry plant weights were quantified using an electronic balance (Acculab VIC 612 - 0,01 g precision). The plants were dried for $48 \mathrm{~h}$ at $70^{\circ} \mathrm{C}$ in a Memmert oven. 
In addition, soil samples were taken with a metal cylinder, $10 \mathrm{~cm}$ diameter and $5 \mathrm{~cm}$ depth. The samples were transported in plastic bags to the laboratory, where the mites were extracted with a modified Berlesse funnel (Oliveira et al., 2000). Each sample was observed with a stereomicroscope (Leica microsystems) to confirm the presence of the Mesostigmata mites. The variables were measured in the laboratories of Biological control and Plant physiology of the UPTC.

The data were subjected to normality and variance homogeneity tests using Shapiro-Wilk and Bartlett tests, respectively. When the assumptions were verified, the variables that had statistical differences were tested with Tukey's comparison of means $(P \leq 0.05)$. The analyses were carried out in $\mathrm{R}$ (version 3.3.2).

\section{RESULTS AND DISCUSSION}

\section{Population estimate of $T$. tabaci in onion plants with $G$. aculeifer and $P$. bituberosus}

The population of T. tabaci in the onion plants declined, with significant differences $(P \leq 0.05)$ between the six treatments with $G$. aculeifer (G50, G75, and G100,) and the control after week seven. The Tukey test corroborated the differences, with $10 \pm 3.6$; $26 \pm 4.3$ and $17 \pm 2.6$ T. tabaci individuals on the leaves, which indicated a 78, 63 and $48 \%$ population decrease for the treatments with G100, G75 and G50 G. aculeifer, respectively (Fig. 1A).
A similar response was observed in the onion plants with $P$. bituberosus after the $9^{\text {th }}$ week, with counts of $13 \pm 2.0 ; 23 \pm 2.4$ and $19 \pm 2.6$ individuals, indicating a reduction of 72,62 , and $55 \%$ in the T. tabaci population, as shown in figure $1 \mathrm{~B}$.

Our results showed a reduction of $48-78 \%$ in the $T$. tabaci population with G. aculeifer and P. bituberosus over 13 weeks. This was comparable to reports for other species of edaphic mesostigmatid mites. For example, Stratiolaelaps scimitus (Womersley) reduced the population density of T. tabaci by $64 \%$ over 6 weeks (Wu et al., 2014), Hypoaspis miles (Berlese) saw a reduction of $44.9 \%$, G. aculeifer (mentioned as $\mathrm{Hy}$ poaspis aculeifer) saw a reduction of $57.6 \%$ for $14 \mathrm{~d}$ (Berndt et al., 2004) and 51\%, and Macrocheles robustulus (Berlese) saw a reduction of $66-70 \%$ for 13 weeks (Messelink and van Holstein-Saj, 2008), feeding on F. occidentalis. However, the edaphic phases of T. tabaci control only provide an alternative within integrated management programs because approximately $20-25 \%$ of thrip populations can complete their life cycle in the presence of predatory mites (Berndt et al., 2004).

These differences in the predation rate may be related to several factors, e.g. slight contortions that have been observed in the pupal stages of thrips (RuedaRamírez et al., 2019), size of the pre pupa and pupa, which are usually smaller $(0.91-0.96 \mathrm{~mm}$ ) (Shaikh et al., 2015) than F. occidentalis (1.1-1.3 mm) (Cárdenas and Corredor, 1989). This may determine the preference of $\mathrm{G}$. aculeifer and P. bituberosus for some types of prey.
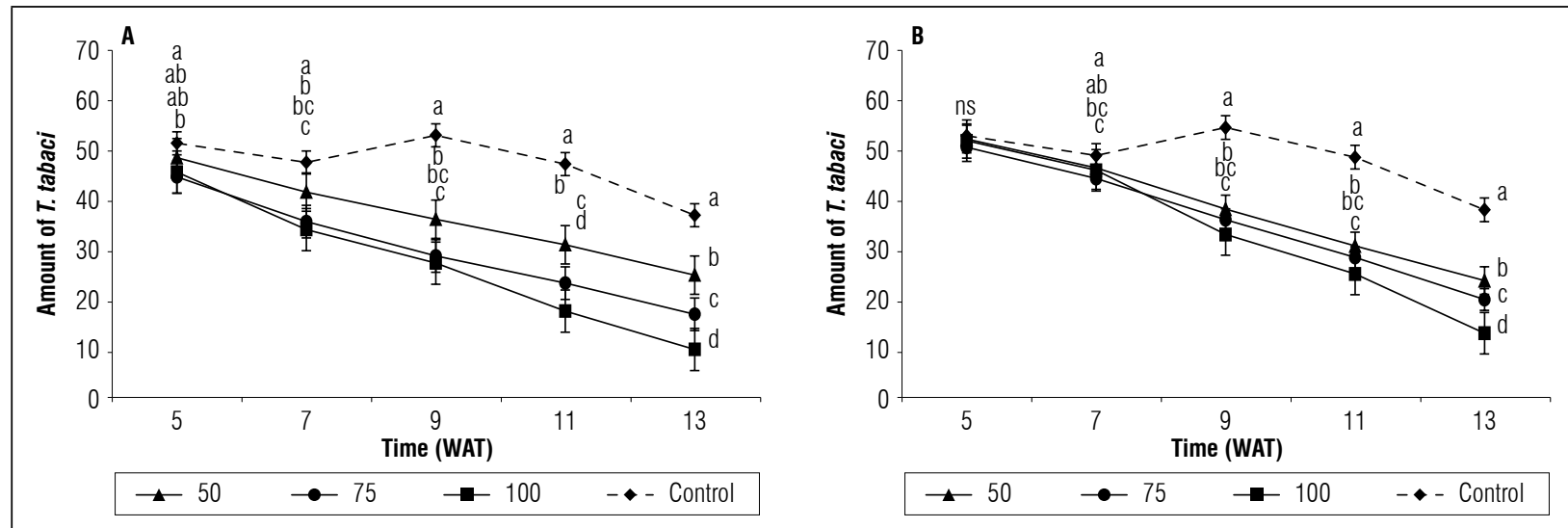

Figure 1. Population density of Thrips tabaci in bulb onion plants (A. cepa) exposed to different concentrations of the predatory mites G. aculeifer (A) and P. bituberosus (B) and a control without application for 13 week after transplant (WAT). Means with different letters indicate a significant statistical difference, and ns indicates no statistical difference according to the Tukey test $(P \leq 0.05)$. The vertical bars indicate \pm standard error. 


\section{Effects on bulb onion plant development with} $G$. aculeifer and $P$. bituberosus

Evaluation of the relative chlorophyll index showed statistical differences $(P \leq 0.05)$ between the treatments after the $7^{\text {th }}$ week, when the bulb formation phase began (Fig. 2). The treatment with 100 individuals of predatory mites presented the highest value for this index in week 13, with $135 \pm 3.4$ SPAD units.

The results in figure 2 indicated that the onion plants infested with G. aculeifer and P. bituberosus had a higher chlorophyll content than the control plants (97 \pm 2.0 SPAD units), and the treatment with $50 P$. bituberosus individuals achieved $103 \pm 3.2$ SPAD Units within 13 weeks, possibly because a small number of $P$. bituberosus mites preferred another type of prey rather than thrips, such as small insects, collembolans and other mites that live in the soil (Castilho et al., 2015).

The leaf area showed significant differences between the treatments. According to the Tukey test $(P \leq 0.05)$, this result was more evident with the treatments where G. aculeifer was added, with an average leaf area for all treatments of $238 \pm 14.7 \mathrm{~cm}^{2}$, while this average for $P$. bituberosus was $220 \pm 9.7 \mathrm{~cm}^{2}$. Both were higher than the control $\left(130 \pm 16.8 \mathrm{~cm}^{2}\right)$ (Fig. 3).

Pineda-Mares et al. (2001) indicated that leaf lamina is one of the most important parts for developing photosynthesis. T. tabaci adults and individual nymphs that perforate the surface tissues to absorb cellular contents interfere with this process (Jensen et al., 2003), directly affecting leaf area (Marschner, 2012). Likewise, the populations of T. tabaci were significantly higher when the crop had a growing period longer than 3 weeks, resulting in longer leaves that can be more attractive for thrips than in seedlings (Hsu et al., 2010). This behaviour was observed here, especially in the control plants.

The dry leaf weight had significant differences between the treatments $(P \leq 0.05)$. The higher values were $52.9 \pm 2.29$ and $55.2 \pm 2.59 \mathrm{~g}$ when 100

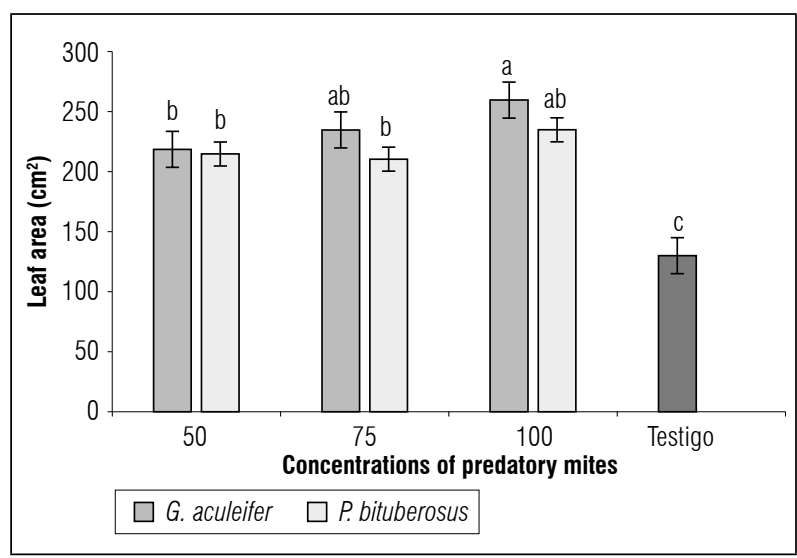

Figure 3. Leaf area in bulb onion plants (A. cepa) exposed to different concentrations of the predatory mites $\boldsymbol{G}$. aculeifer and $\boldsymbol{P}$. bituberosus and a control without application. Means with different letters indicate a significant statistical difference according to the Tukey test $(P \leq 0.05)$. The vertical bars indicate \pm standard error.
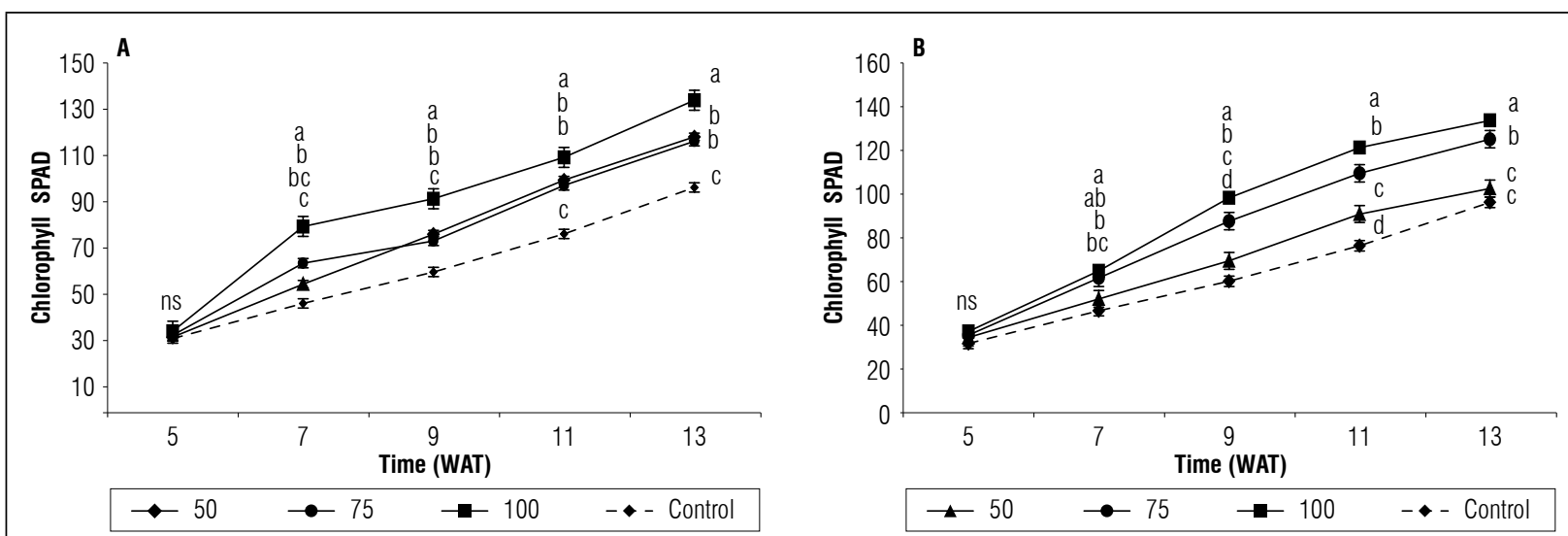

Figure 2. Relative chlorophyll index SPAD in bulb onion plants (A. cepa) exposed to different concentrations of the predatory mites $G$. aculeifer (A) and $P$. bituberosus (B) and a control without application in the $13^{\text {th }}$ week after transplant (WAT). Means with different letters indicate a significant statistical difference, and ns indicates no statistical difference according to the Tukey test $(P \leq 0.05)$. The vertical bars indicate \pm standard error. 
individuals of G. aculeifer or P. bituberosus were added, respectively (Fig. 4). In comparison, the control treatment presented the lowest value with $28.2 \pm 1.78 \mathrm{~g}$, indicating a negative effect when onion plants do not have any control for $T$. tabaci because the nutrient supply is directly related to the accumulation of dry matter (Hernández et al., 1996).

A decrease in the dry matter was observed in figure 4 , indicating that there was a decrease in the uptake and efficiency of radiation, as reflected in the accumulation of dry matter in the onion plants. Since this parameter indicates the amount of photoassimilates stored in different parts for plant growth (EstradaOrtiz et al., 2011), directly affecting production, conversion of simple sugars in leaf tissue and bulb growth (Dogliotti et al., 2011) (Fig. 5).

In terms of fresh bulb weight, there were significant differences between the treatments $(P \leq 0.05)$. The higher weights were 1,341.15 $\pm 29.1 \mathrm{~g}$ and $1,188.36 \pm 12 \mathrm{~g}$ with the presence of 100 individuals of $G$. aculeifer or P. bituberosus, respectively. Additionally, the weight with the release of $50 P$. bituberosus mites $(618.3 \pm 16.2 \mathrm{~g})$ was remarkably similar to the control (620.1 $\pm 29.3 \mathrm{~g}$ ) (Fig. 5) because the number of soil predatory mites was not sufficient for managing T. tabaci, affecting the fresh bulb weight.

The chlorophyll content is directly related to the photosynthetic rate (Shekari et al., 2017), so, direct damage by $T$. tabaci destroys the mesophyll, affecting the

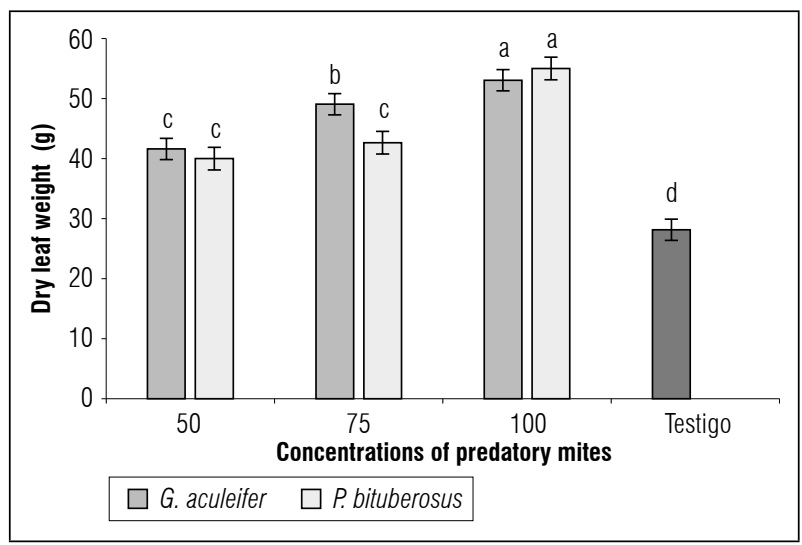

Figure 4. Dry leaf weight in bulb onion plants (A. cepa) exposed to different concentrations of the predatory mites G. aculeifer and $\boldsymbol{P}$. bituberosus and a control without application. Means with different letters indicate a significant statistical difference according to the Tukey test $(P \leq 0.05)$. The vertical bars indicate \pm standard error. amount of chlorophyll in the leaf (Molenaar, 1984) and interfering with the transport of nutrients to the bulb (Parrella and Lewis, 1997; Diaz-Montano et al., 2011). On the other hand, a higher production of ethylene is induced in onion plants when the salivary gland products of T. tabaci affect tissues (Kendall and Bjostad, 1990), inducing early maturation and senescence of the leaves (Levy and Kedar, 1970). This was observed in the present study because the control had the lowest values for the evaluated variables, such as leaf area, leaf dry weight and fresh bulb weight, as reflected in the growth and development of the onion plants.

Despite the physiological differences obtained with the predatory mite releases evaluated in the onion plants, alternative management strategies are recommended to suppress populations of $T$. tabaci because combined strategies result in more efficient insect pest control. For example, S. scimitus and Gaeolaelaps gillespiei (Beaulieu) (Mesostigmata: Laelapidae), when used with Metarhizium anisopliae (Metschnikoff) and Beauveria bassiana (Balsamo), achieved a mortality greater than $90 \%$ for F. occidentalis (Saito and Brownbridge, 2016). These components may be considered for future research and field verification, especially for the protection of bulb onion leaves, where juvenile and adult T. tabaci are found, playing an important role in reducing yield by damaging crops (Jandricic et al., 2016).

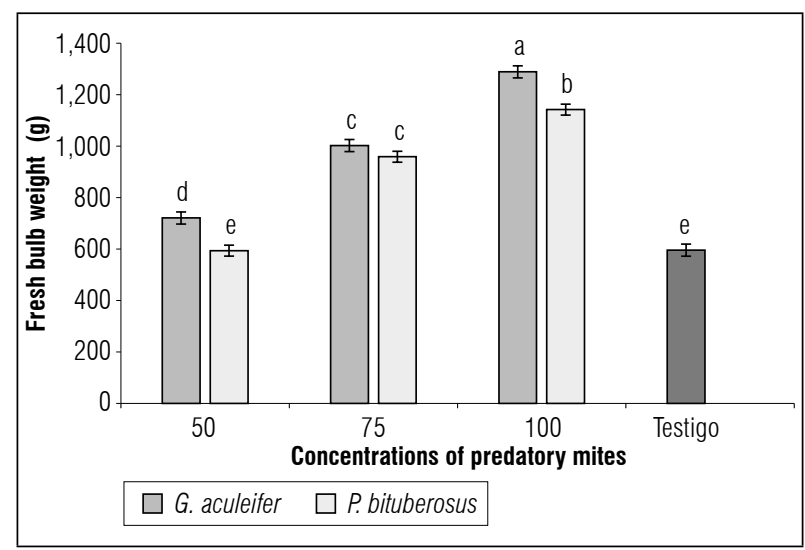

Figure 5. Fresh bulb weight $(\mathrm{g})$ in bulb onion plants $(A$. cepa) exposed to different concentrations of the predatory mites $\boldsymbol{G}$. aculeifer and $\boldsymbol{P}$. bituberosus and a control without application. Means with different letters indicate a significant statistical difference according the to Tukey test $(P \leq 0.05)$. The vertical bars indicate \pm standard error. 


\section{CONCLUSIONS}

The results in this research indicated that releasing the predatory mites $G$. aculeifer and P. bituberosus reduced the population of T. tabaci by 72 and $78 \%$, respectively. Consequently, the relative chlorophyll index, leaf area index, dry leaf weight and fresh bulb weight increased when compared to the onion plants without a control for this bulb onion insect pest.

The highest values in the physiological variables, which contribute to the yield of bulb onion crops, were obtained with the release of 100 individuals of G. aculeifer or P. bituberosus, representing a new tool for integrated management programs for $T$. tabaci.

\section{ACKNOWLEDGMENTS}

This research was carried out with the support of Vicerrectoria de investigación y extension and the Grupo Manejo Biologico de Cultivos at the Universidad Pedagógica y Tecnológica de Colombia, Tunja. Research project code SGI-2335. The authors thank Diana Rueda Ramirez of Explora Agrotecnologia for providing G. aculeifer and P. bituberosus individuals when the colonies decreased.

Conflict of interests: The manuscript was prepared and reviewed with the participation of the authors, who declare that there exists no conflict of interest that puts at risk the validity of the presented results.

\section{BIBLIOGRAPHIC REFERENCES}

Al-Amidi, A.H.K. and M.J. Downes. 1990. Parasitus bituberosus (Acari: Parasitidae), a possible agent for biological control of Heteropeza pygmaea (Diptera: Cecidomyiidae) in mushroom compost. Exp. Appl. Acarol. 8, 1325. Doi: $10.1007 /$ BF01193378

Al-Amidi, A.H.K., R. Dunne, and M.J. Downes. 1991. Parasitus bituberosus (Acari: Parasitidae): An agent for control of Lycoriella solani (Diptera: Sciaridae) in mushroom crops. Exp. Appl. Acarol. 11, 159-166. Doi: 10.1007/BF01246088

Berndt, O., H.-M. Poehling, and R. Meyhöfer. 2004. Predation capacity of two predatory laelapid mites on soil-dwelling thrips stages. Entomol. Exp. Appl. 112(2), 107-115. Doi: 10.1111/j.0013-8703.2004.00185.x

Cárdenas, E. and D. Corredor. 1989. Biología del trips Frankliniella occidentalis (Pegande) (Thysanoptera: Thripidae) sobre crisantemo Chrysanthemum morifolium L. bajo condiciones de laboratorio. Agron. Colomb. 6(12), 71-77.
Carrillo, D., G.J. Moraes, and J.E. Peña (eds.). 2015. Prospects for biological control of plant feeding mites and other harmful organisms. Progress in Biological Control. Vol. 19. Springer International Publishing, Cham, Switzerland. Doi: 10.1007/978-3-319-15042-0

Castilho, R.C., R. Venancio, and J.P.Z. Narita. 2015. Mesostigmata as biological control agents, with emphasis on Rhodacaroidea and Parasitoidea. pp 1-32. In: Carrillo, D., G.J. Moraes, and J.E. Peña (eds.). Prospects for biological control of plant feeding mites and other harmful organisms. Progress in Biological Control. Vol. 19. Springer International Publishing, Cham. Doi: 10.1007/978-3-319-15042-0_1

Castro-López, M. 2018. Ácaros Mesostigmata como potenciales controladores de Thrips tabaci Lindeman en el cultivo de cebolla Allium cepa L. MSc thesis. Facultad de Ciencias Agrarias, Universidad Nacional de Colombia, Bogota.

Damte, T., G. Tabor, M. Haile, G. Mitiku, and T. Lulseged. 2017. Determination of beginning of bulb enlargement time in shallot, Allium cepa var aggregatum for managing onion thrips (Thrips tabaci). Sci. Hortic. 220, 154-159. Doi: 10.1016/j.scienta.2017.03.035

Diaz-Montano, J., M. Fuchs, Nault, B.A. Nault, J. Fail, and A.M. Shelton. 2011. Onion thrips (Thysanoptera: Thripidae): A global pest of increasing concern in onion. J. Econ. Entomol. 104(1), 1-13. Doi: 10.1603/ EC10269

Dogliotti, S., P. Colnago, G. Galván, and L. Aldabe. 2011. Bases fisiológicas del crecimiento y desarrollo de los principales cultivos hortícolas: Tomate (Lycopersicum sculentum), papa (Solanun tuberosum) y cebolla (Allium cepa). pp. 39-57. Curso de Fisiología de los CultivosMódulo Horticultura, Facultad de Agronomía, Universidad de la República de Uruguay, Montevideo.

Estrada-Ortiz, E., L.I. Trejo, F.C. Gómez-Merino, M. Sandoval-Villa, and R. Núñez-Escobar. 2011. Respuestas bioquímicas en fresa al suministro de fósforo en forma de fosfito. Rev. Chapingo Ser. Hortic. 17(3), 129-138. Doi: 10.5154/r.rchsh.2011.17.024

Freire, A.R.P. and G.J. Moraes. 2007. Mass production of the predatory mite Stratiolaelaps scimitus (Womersley) (Acari: Laelapidae). Syst. Appl. Acarol. 12(2), 117-119. Doi: http://dx.doi.org/10.11158/saa.12.2.4

Gill, H., K.H. Garg, A.K. Gill, J.L. Gillett-Kaufman, and B.A. Nault. 2015. Onion thrips (Thysanoptera: Thripidae) biology, ecology, and management in onion production systems. J. Integr. Pest Manag. 6(1), 2155-7470. Doi: $10.1093 / \mathrm{jipm} / \mathrm{pmv} 006$

Heckmann, L.-H., A. Ruf, K.M. Nienstedt, and P.H. Krogh. 2007. Reproductive performance of the generalist predator Hypoaspis aculeifer (Acari: Gamasida) when foraging on different invertebrate prey. Appl. Soil Ecol. 36(2-3), 130-135. Doi: 10.1016/j.apsoil.2007.01.002 
Hernández, G., V. Toscano, N. Méndez, L. Gómez, and M. Mullings. 1996. Efecto de la concentración de fósforo sobre su asimilación en tres genotipos de fríjol común (Phaseolus vulgaris L.). Agron. Mesoam. 7(1), 80-85. Doi: 10.15517/am.v7i1.24794

Hsu, C.L. C.A. Hoepting, M. Fuchs, A.M. Shelton, and B.A. Nault. 2010. Temporal dynamics of iris yellow spot virus and its vector, Thrips tabaci (Thysanoptera: Thripidae), in seeded and transplanted onion fields. Environ. Entomol. 39(2), 266-277. Doi: 10.1603/EN09165

Jandricic, S.E., D. Schmidt, G. Bryant, and S.D. Frank. 2016. Non-consumptive predator effects on a primary greenhouse pest: Predatory mite harassment reduces western flower thrips abundance and plant damage. Biol. Control 95, 5-12. Doi: 10.1016/j. biocontrol.2015.12.012

Jensen, L.B., B.C. Simko, C.C. Shock, and L.D. Saunders. 2003. A two-year study on alternative methods for controlling onion thrips (Thrips tabaci L.) in Spanish onions. OSU Agricultural Experiment Station - Special Report 1048, 94-106.

Kendall, D.M. and L.B. Bjostad. 1990. Phytohormone ecology: herbivory by Thrips tabaci induces greater ethylene production in intact onions than mechanical damage alone. J. Chem. Ecol. 16, 981-991. Doi: 10.1007/BF01016506

Lebedev, G. F. Abo-Moch, G. Gafni, D. Ben-Yakir, and M. Ghanim. 2013. High-level of resistance to spinosad, emamectin benzoate and carbosulfan in populations of Thrips tabaci collected in Israel. Pest Manag. Sci. 69(2), 274-277. Doi: 10.1002/ps.3385.

Levy, D. and N. Kedar. 1970. Effect of ethrel on growth and bulb initiation in onion. HortScience 5, 80-82.

Marschner, P. (ed.). 2012. Mineral nutrition of higher plants. $3^{\text {rd }}$ ed. Elsevier, Oxford, UK.

Martin, N.A., P.J. Workman, and R.C. Butler. 2003. Insecticide resistance in onion thrips (Thrips tabaci) (Thysanoptera: Thripidae). N.Z.J. Crop Hortic. Sci. 31(2), 99-106. 10.1080/01140671.2003.9514242.

Messelink, G. and R. van Holstein-Saj. 2008. Improving thrips control by the soil-dwelling predatory mite Macrocheles robustulus (Berlese). Integrated Control in Protected Crops, Temperate Climate IOBC/wprs Bulletin 32, 135-138.

Molenaar, N.D. 1984. Genetics, thrips (Thrips tabaci L.) resistance and epicuticular wax characteristics of nonglossy and glossy onions (Allium cepa L.). PhD thesis. University of Wisconsin, Madison, WI.

Moreira, G.F. and G.J. Moraes. 2015. The potential of free-living Laelapid mites (Mesostigmata: Laelapidae) as biological control agents. pp. 77-102. In: Carrillo, D., Moraes, G.J. de, and Peña, J.E. (eds.), Prospects for biological control of plant feeding mites and other harmful organisms. Progress in Biological Control.
Vol. 19. Springer International Publishing, Cham. Doi: 10.1007/978-3-319-15042-0_3

Muñoz, R.M., M.L. Lerma, P. Lunello, and H.F. Schwartz. 2014. Iris yellow spot virus in Spain: incidence, epidemiology, and yield effect on onion crops. J. Plant Pathol. 96(1), 97-103. Doi: http://dx.doi.org/10.4454/ JPP.V9611.029

Navarro-Campos, C., A. Pekas, M.L. Moraza, A. Aguilar, and F. Gracia-Marí. 2012. Soil-dwelling predatory mites in citrus: their potential as natural enemies of thrips with special reference to Pezothrips kellyanus (Thysanoptera: Thripidae). Biol. Control 63(2), 201209. Doi: 10.1016/j.biocontrol.2012.07.007

Oliveira, A.R., G.J. Moraes, C.G.B. Demétrio, and E.A.B. Nardo. 2000. Efeito do virus de poliedrose nuclear de Anticarsia gemmatalis sobre Oribatida edaficos (Arachnida; Acari) em um campo de soja. Boletim de Pesquisa 13. Embrapa Meio Ambiente, Jaguariuna, Brazil. pp. 5-31.

Parrella, M.P. and T. Lewis. 1997. Integrated pest management (IPM) in field crops. pp. 595-614. In: Lewis, T. (ed.). Thrips as crop pests. CAB International, Wallingford, UK.

Pineda-Mares, P., M.J. Martínez, O.A. Amante, and V.V. Ruiz. 2001. Respuesta del maíz al fósforo y un mejorador de suelos en áreas yesosas de la zona media de San Luis de Potosí. Rev. Chapingo Ser. Zonas Áridas 2, 106-113.

Pinzón, H. 2009. Los cultivos de cebolla y ajo en Colombia: estado del arte y perspectivas. Rev. Colomb. Cienc. Hortic. 3(1), 45-55. 10.17584/rcch.2009v3i1.1198.

Rueda, A., F.R. Badenes-Pérez, and A.M. Shelton. 2007. Developing economic thresholds for onion thrips in Honduras. Crop Prot. 26(8), 1099-1107. Doi: 10.1016/j. cropro.2006.10.002

Rueda-Ramírez, D., D.M. Ríos-Malaver, A. Varela-Ramírez, and G.J. Moraes. 2018. Colombian population of the mite Gaeolaelaps aculeifer as a predator of the thrips Frankliniella occidentalis and the possible use of an astigmatid mite as its factitious prey. Syst. Appl. Acarol. 23(12), 2359-2372. Doi: http://dx.doi.org/10.11158/ saa.23.12.8.

Rueda-Ramírez, D., D. Ríos-Malaver, A. Varela-Ramírez, and G.J. Moraes. 2019. Biology and predation capacity of Parasitus bituberosus (Acari: Mesostigmata: Parasitidae) on Frankliniella occidentalis (Thysanoptera: Thripidae), and free-living nematodes as its complementary prey. Pest Manag. Sci. 75(7), 1819-1830. Doi: $10.1002 /$ ps.5326.

Saito, T. and M. Brownbridge. 2016. Compatibility of soil-dwelling predators and microbial agents and their efficacy in controlling soil-dwelling stages of western flower thrips Frankliniella occidentalis. Biol. Control. 92, 92-100. Doi: 10.1016/j.biocontrol.2015.10.003 
Sardar, M.A. and P.W. Murphy. 1987. Feeding tests of grassland soil-inhabiting gamasine predators. Acarologia 28(2), 117-121.

Shaikh, R.R., M.F. Acharya, and N.S. Rode. 2015. Bionomics of Thrips tabaci Lindeman on onion. J. Exp. Zool. India 18(1), 457-459.

Shekari, F., A. Abbasi, and S. Mustafavi. 2017. Effect of silicon and selenium on enzymatic changes and productivity of dill in saline condition. J. Saudi Soc. Agric. Sci. 16(4), 367-374. Doi: 10.1016/j.jssas.2015.11.006

Shelton, A.M., J.Z. Zhao, B.A. Nault, J. Plate, F.R. Musser, and E. Larentzaki. 2006. Patterns of insecticide resistance in onion thrips (Thysanoptera: Thripidae) in onion fields in New York. J. Econ. Entomol. 99(5), 1798-1804. Doi: 10.1093/jee/99.5.1798

Szafranek, P., M. Lewandowski, and M. Kozak. 2013. Prey preference and life tables of the predatory mite
Parasitus bituberosus (Acari: Parasitidae) when offered various prey combinations. Exp. Appl. Acarol. 61, 5367. Doi: 10.1007/s10493-013-9701-y

van Lenteren, J.C. 2012. The state of commercial augmentative biological control: Plenty of natural enemies, but a frustrating lack of uptake. BioControl 57, 1-20. Doi: 10.1007/s10526-011-9395-1

Vergel, M., J.J. Martínez, and S.L. Zafra. 2017. Cultivo de cebolla y su comportamiento en la Provincia de Ocaña. Rev. Colomb. Cienc. Hortic. 10(2), 333-344. Doi: 10.17584/rcch.2016v10i2.5070

Wu, S., Y. Gao, X. Xu, E. Wang, Y. Wang, and Z. Lei. 2014. Evaluation of Stratiolaelaos scimitus and Neoseiulus barkeri for biological control of thrips on greenhouse cucumbers. Biocontrol Sci. Tech. 24(10), 1110-1121. Doi: 10.1080/09583157.2014.924478 